\title{
EHMTI-0214. Headache syndromes - known to the unknown?
}

\author{
$\mathrm{KRaO}^{1 *}$, J Rekha², S Mohan ${ }^{3}$ \\ From 4th European Headache and Migraine Trust International Congress: EHMTIC 2014 \\ Copenhagen, Denmark. 18-21 September 2014
}

\section{Background}

Headache, is a widely prevalent and a common clinical problem across the world.Primary headaches form the majority with the current prevalence of headache estimated to be $47 \%$, globally (WHO). Migraine and TTH are the two commonest. Few headache disorders could raise controversy in diagnosis and treatment.Some headaches which appear like primary(migraine,TAC,TTH etc.)or the known secondary ones may have few peculiar/interesting findings contrary to the conventional descriptions \& can pose challenges to the diagnosis,classification and also treatment.

\section{Aim}

To critically analyse \& try understanding the mechanisms in both primary and some of the secondary ones which are atypical in their presentation when critically looked at from a clinical, radiological and treatment point of view.

\section{Methods}

25 cases of different types were meticulously looked into. Detailed clinical data,supportive investigations, radiological findings (MRI/CTangio) CSF/opthalmological examination findings (selected) treatment \& clinical course on follow up.

\section{Results}

25 cases (F:M-1.5:1) in the age group (16-69years). Various types of headaches with f/o migraine, TAC, CDH (IHS criteria) were noted. 4 of those had overlapping features. 2 had recent onset daily headache associated with binocular diplopia, s/o raised ICT. 1 had two episodes of headache with transient binocular diplopia. One had classical s/o TAC at presentation. Rest had strictly unilateral headache with subtle autonomic features mimicking TAC.

${ }^{1}$ Neurology, Gokulam Hospital, Salem, India

Full list of author information is available at the end of the article
Radiological abnormalities were seen in all excepting 2. Three cases mimicking BIH had normal MRV with abnormal CSF in 1 and all 3 had abnormal thyroid functions. Treatment was individualized and clinical response to drug regimens was varied.

\section{Conclusions}

Headaches can be extremely challenging in their manifestations. Many, though appear to mimic the known ones, can have atypical findings when looked in critically. These could raise controversies in classification \& treatment.

No conflict of interest.

\section{Authors' details}

${ }^{1}$ Neurology, Gokulam Hospital, Salem, India. ${ }^{2}$ Radiology, Gokulam Hospital, Salem, India. ${ }^{3}$ Medicine, Gokulam Hospital, Salem, India.

Published: 18 September 2014

doi:10.1186/1129-2377-15-S1-C53

Cite this article as: Rao et al.: EHMTI-0214. Headache syndromes known to the unknown? The Journal of Headache and Pain 2014

15(Suppl 1):C53.

Submit your manuscript to a SpringerOpen ${ }^{\odot}$ journal and benefit from:

- Convenient online submission

- Rigorous peer review

- Immediate publication on acceptance

- Open access: articles freely available online

- High visibility within the field

- Retaining the copyright to your article

Submit your next manuscript at $\gg$ springeropen.com

\section{SpringerOpen ${ }^{\circ}$}

(C) 2014 Rao et al; licensee Springer. This is an Open Access article distributed under the terms of the Creative Commons Attribution License (http://creativecommons.org/licenses/by/2.0), which permits unrestricted use, distribution, and reproduction in any medium, provided the original work is properly cited. 